Journal of Mobile Communication 4 (3): 68-74, 2010

ISSN: 1990-794X

(C) Medwell Journals, 2010

\title{
Cell Phone Usage and Travel Behaviour in Ondo State, Nigeria
}

\author{
E.F. Ogunbodede \\ Department of Geography and Planning Sciences, \\ Faculty of Social and Management Sciences, Adekunle Ajasin University, Akungba Akoko, Nigeria
}

\begin{abstract}
The study examines the state of the practice of the cell phone usage in Ondo State and its effects on travel behaviour of six hundred respondents who were purposively selected from six major towns. This was because controversies surrounded the potentials of cell phone usage as a means of reducing inter-urban travels than when one is using automobiles. Therefore, questions relating to socio-economic background of respondents, effect of cell phone usage on physical travels as well as how it affects pattern of travel of respondents were asked. Findings revealed that people prefer making interaction using their mobile phones than embarking on physical travels. Weekly and seasonal travels have been reduced, while calls have grown astronomically. This has made commuters to spend more on buying recharge cards to enable them make more contacts rather than embark on physical contacts. The cell phone usage has therefore afforded the consumers the opportunity to interact with friends, relations, workers and neighbours without necessarily embarking on any journeys. This mode of contact according to respondents has reduced the frequency of commercial vehicles on the road as well as the frequency of accident occuring on the roads. However, unreliable network of one GSM or the other and the importance attached to calls has made people to patronize more than one GSM (network) in order to link the world at any point in time. This has exerted additional strains on the resources (disposable income) income of the people of Ondo State.
\end{abstract}

Key words: GSM, physical contacts, cell phone, travel behavior, weekly and seasonal travels

\section{INTRODUCTION}

There is no doubt that the telecommunication system in Nigeria has undergone a revolution since the deregulation of the market in the year 2000. Ever since then there had been an astronomical growth in the acquirement of cell phone by youths, grown-ups and the aged people. Similarly the Nigerian communication commission (NSS), seeing the robust growth in the sector, encouraged the entry of more mobile operators into the market in the year 2001. This has influenced the tele-density which rose from $0.73 \%$ in December 2001 to $26.47 \%$ in August 2007 and the market witnessed increased records of investment on daily basis Corporate Nigeria.

Telecommunication in Nigeria enjoys state monopoly for a long time before it became available in open market. After its establishment in 1985, the parastatal, Nigerian Telecommunication (NITEL) had a monopoly in the country in spite of its poorly maintained infrastructures and long waiting times for connections. In year 2001, the NCC held on open auction for GSM licenses which were issued to NITEL; operating as M-Tel, South African telecoms company as MTN and a consortium led by Zimbabwe's as Econet wireless. According to Corporate
Nigeria, the entry of the mobile operators immediately changed NITEL's control of the market. Consumers saw that mobile phones offered better opportunities than the limited fixed-line infrastructure offered by NITEL. This influenced the growth in mobile phone and by year 2002, there were over 1.5 million mobile subscribers in the country as against 702,000 fixed-line subscribers. By august 2007, Mobile subscriptions of 43,066,679 were available compared to 2,035,235 fixed lines.

Since, the introduction of mobile system (GSM) in Nigeria and Ondo State in particular, the usage of cell phones and the pattern of the travel behaviour of the people have changed. Before the introduction of the GSM, the people had no choice other than to depend on the use of automobile to commute between towns (inter-urban travels).

This dependency is associated with a lot of transportation problems such as accidents, traffic congestions and robbery. In terms of similarity, both the GSM and physical travel (using automobiles) offer a means of achieving some interaction that keep social, cultural, economic and political activities going (Ogunbodede, 2005). The two terms however, differ when transportation is considered as physical movement of persons, goods and information while telecommuting is 
seen as a means of sending information through electronic media (cell phone, telephone, walkie-talkie and the likes) without physical contact.

Ondo State which is made up of eighteen local government areas has many urban centres in addition to the headquarters of each local government. These centres interact and people had to contend with transportation problems but with the use of GSM, a lot of physical interaction is said to have been reduced. The extent to which GSM has altered travel behaviour, especially, inter-urban travels, has not been fully reported or given attention in the literature. Apart from this, controversies surrounding the potentials of cell phone usage as a means of reducing inter-urban travels also constitute the motivation for embarking on this research.

Statement of problem: Information dissemination between and within states were carried out loosely by the use of automobiles in Nigeria in spite the fact that NITEL was in operation before year 2001. This was because, NITEL serves the affluent in the society hence their services were not within the reach of the poor. Apart from this, establishment of telecommunication industry in the country in year 1881 till it metamorphosed into NITEL in 1985 had some structural and administrative problems. It was difficult for an average Nigerian to have access to telephone facilities through NITEL. According to Olufayo and Omotosho (2008), this was as a result of the financial and administrative problems associated with obtaining telephone lines. The difficulties people have in having access to this telecommunication (NITEL) which was the only single national carrier obtainable in Nigeria before the advent of GSM reduced the number of people that subscribed to this facilities.

Studies in the past shows that most cities all over the world have been automobile dependant for a very long time. For example, in North America, transportation cost represents a larger portion of household expenditure than other parts of the world despite relative low prices for individual components, such as vehicles and fuels (Hook, 1995). The same is experienced in Nigeria intra-city travels as well as inter-urban travels. Automobile dependency without considering other alternatives to means of movement is beset with a lot of problems, such as accidents, traffic congestion and robbery of passengers by armed robbers on the highways.

There are recognizable travel patterns in the movement of people who commute on daily or weekly or seasonally basis within and between cities. While in cities, three peak periods are recognized on daily basis (morning, afternoon and evening), intra-urban travels exhibits weekly and seasonal patterns. The Mondays and Fridays are the most frequent days of the week when inter-urban travels are common in Nigeria. This is because people travel to meet their relations as well as attend social functions often during the weekend. It is this type of travel (inter-urban travels) that is on the increase that causes accidents as well as targets for armed robbers. This type of traveling is also associated with physical stress and could be avoided if it is only meant to disseminate information or message.

The aim of this study is to examine the state of the practice of the cell phone usage in Ondo State and determine its effect on travel behaviour of its people.

Theoretical background: Past studies have revealed recognizable, regular and predictable temporal pattern of movement in towns and cities (Daniels and Warnes, 1980; Bello, 1994; Galtima, 1988). The principal rhythms of travel are diurnal, weakly and seasonal. On a daily basis, urban travels has three peak periods (Morning, afternoon and evening) while on a weekly basis, there are movement in and out of the city on Mondays and Fridays. On a seasonal basis, the peaks of movement (inter-urban travels) coincide with the festive periods like the Easter holidays and Christmas period (for the Christians), during the Muslim festive periods like Id-el-karbir and Id-el-Fitre, as well as other special periods like Yam Eating Festivals, Masquerade festivals and other deity festivals.

Existing studies (Hay and Smith, 1970; Ogunsanya, 1982) have shown on regional or macro scale that some pattern discerning techniques can be used in the identification of spatial pattern of flows between regions. One of such method is the use of non-routed cartographic technique.

Ogunsanya (1982) used the non-routed cartographic technique to depict the result of the overall pattern of intra-metropolitan freight flow between fourteen sectors of the city of Lagos. The overall pattern appears blured indicating the complexity of intra metropolitan freight flow and the inefficiency of the non-routed flow map in describing intra-urban travel pattern. To overcome this defects of the cartographic technique in discerning intra-city flow pattern, Berry (1960) demonstrated how the factor analysis (statistical techniques) can be used. It was therefore obvious from the two examples cited that pattern of movement can easily be carried out using intra-urban travel pattern because the method assists in the identification of major consuming regions (point of 
distraction) and their important producing sources (point of origin). Another concept that is relevant to this study is the growing interest in communication and transportation technology. Some researchers are of the opinion that communication enhances interaction (Mokhatarian and Meenakshisundaram, 1999), some believed that telecommuting acts as a substitute while others are of the opinion that it compliments. According to Adenle (1995), the proponents of the substitution idea argued that a situation is created whereby telecommuting through the use of telephone facilities, usually computeraided system in developing world results in either a positive or negative change in people's travel behaviour.

The extent to which the theoretical underpinning of intra-urban travels in the past fit into the present is examined in this study. Thus, this study aims at examining the state of the practice of the cell phone usage in Ondo State and its effects on travel behavior.

The study area: The study area is Ondo State which was created out of former Ondo Province of Former Western State in 1976. It is bounded by Kwara and Kogi State in the North, Edo State to the East, Delta State to the South
East, Osun and Ogun States to the West and the Bight of Benin of the Atlantic Ocean to the South. The State has mangrove forest to the South, tropical rain forest in the middle and Guinea Savanah towards the extreme northern part (Fig. 1). Agriculture is the main stay of the economy of the people and they produce both cash and food crops. The state is primarily inhabited by the Yoruba people with a tradition of living in towns.

The landmass of the State is 14,606 square $\mathrm{km}$ with a population of 3,441,024 (NPC, 2006). The state has Eighteen Local Government Headquarters which wear urban status by all criteria. Other towns which are not headquarters but with urban status are also many in the State. There are constant movements of people from the Local Government Area headquarters to the State capital (Akure). Similarly there are constant and daily movements of people living in the different towns for business, social, educational and official purposes. Some of these movements involve dissemination of information or messages which were achieved using motorised means of movement before the advent of GSM. The advent of cell phone has curtailed physical movement.
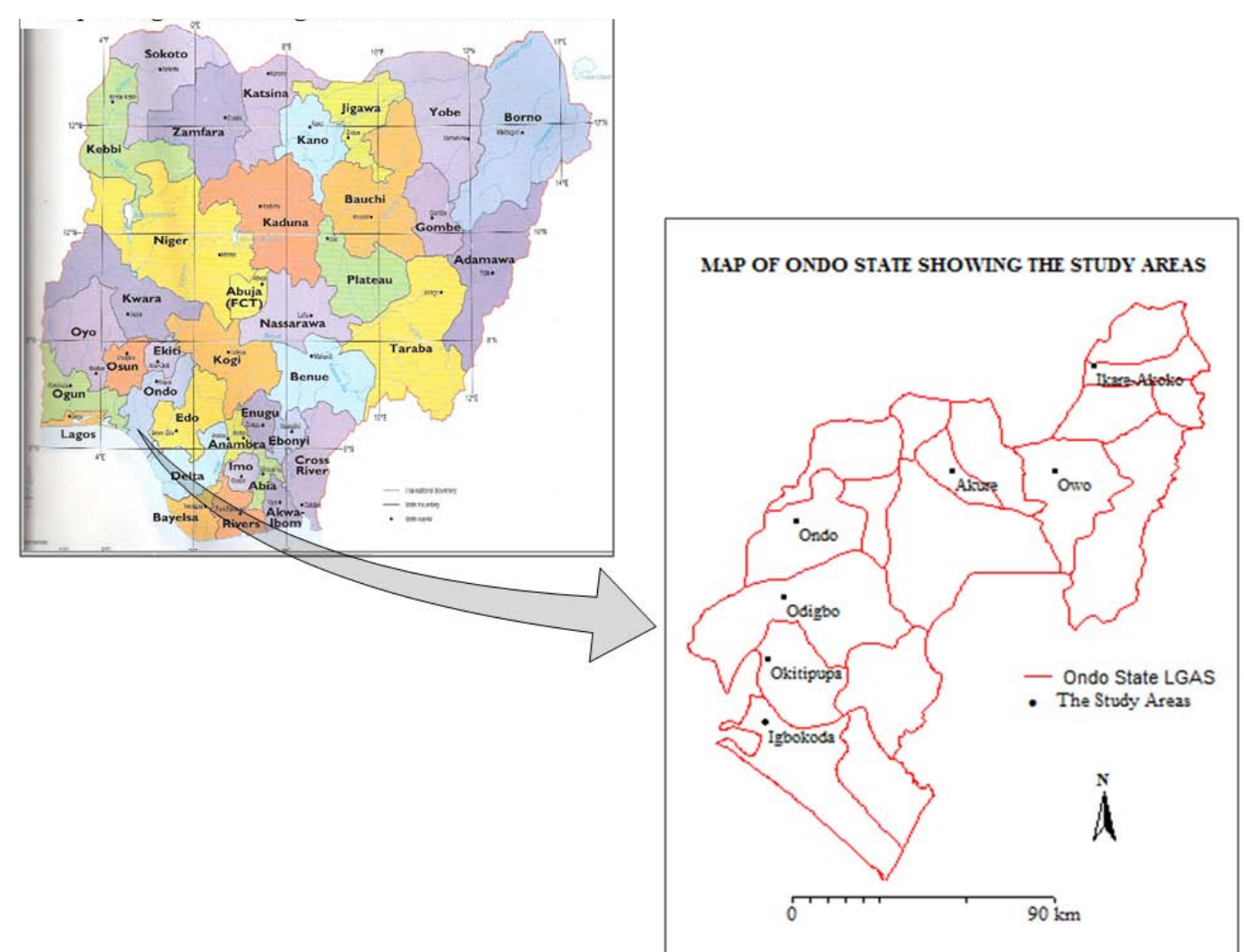

Fig. 1: Map of Nigeria showing the 36 States and the ECT 


\section{MATERIALS AND METHODS}

A well designed questionnaire was carefully packaged to elicit information from cell phone users in the study area. Six hundred questionnaires were randomly distributed to six major towns that were Local Government Area Headquarters (LGA) in Ondo State. The LGA headquarters were purposely selected from the three senatorial Districts in equal proportions. The selected LGA headquarters are Ikare-Akoko, Owo, Akure, Ore, Okitipupa and Igbokoda. In addition to being the administrative headquarters of their LGAs, the towns are the major foci of social, political and social setting of the people. A large population of the people living in the sampled towns could read, comprehend and write; as such it was easy to administer the questionnaire to the sampled people. The data needed and which were collected through the use of the questionnaire include socio-economic variables of the respondents, perception of respondents on the incidence of road accident in the state, average number of cell phones owned per respondents, reliance of respondents on cell phone as against automobile usage to interact within the state and behaviour of respondents in Ondo State.

Data analysis: Questions were specifically aimed at examining the influence of cell phone usage on travel behaviour in Ondo State. The questions were organized into two sections. The first section requires response on socio-economic variables, number of cell phones owned by each households and reliance on use of cell phone in preference to physical movement. Tables of percentages were generated from responses given while the second section is on the perception of respondent on the impact of cell phone usage on travel behaviour in Ondo State. The 4 point-likert scale was used with the options of strongly agree, agree, disagree and strongly disagree and with weighted scale of 4, 3, 2 and 1, respectively. Each statement item (Table 1) highlighting a particular

Table 1: Average number of handsets owned per respondent No. of handsets owned by each respondent

\begin{tabular}{|c|c|c|c|c|}
\hline \multirow[b]{2}{*}{ Sample towns } & \multicolumn{4}{|c|}{ No. of handsets owned by each respondent } \\
\hline & 1 & 2 & 3 & 4 \\
\hline Akure & 48.00 & 42.00 & 8.0 & 2.00 \\
\hline Owo & 57.00 & 39.00 & 4.0 & 0.00 \\
\hline Ikare & 52.00 & 46.00 & 2.0 & 0.00 \\
\hline Ondo & 47.00 & 45.00 & 3.0 & 5.00 \\
\hline Ore & 49.00 & 44.00 & 7.0 & 0.00 \\
\hline Okitipupa & 51.00 & 46.00 & 3.0 & 0.00 \\
\hline Total & 304.00 & 262.00 & 27.0 & 07.00 \\
\hline$\underline{\text { Percentage }}$ & 50.67 & 43.67 & 4.5 & 1.17 \\
\hline
\end{tabular}

perception was used to calculate the Mean Weight Volume (MWV) or Mean of a group data and recorded.

The Group Arithmetic Mean (GAM) was applied to all the calculated mean of a group data and also recorder. The (GAM result was used as a baseline cut-off mark to accept or reject a problem item as being accepted or rejected by the majority.

\section{RESULTS AND DISCUSSION}

The study revealed that overwhelming majority of the respondents was below the age of 60 years $(91.5 \%)$ while $8.5 \%$ are above 61 years of age (Table 2 ). The implication of this age group as users of cell phone and their responses on travel behaviour is that they constitute economically viable set of people who have capacity to embark on physical movement. Thus, they can make reliable behaviour in Ondo State. The educational levels of the respondents as revealed in this study also shows that $79.5 \%$ of them have secondary and tertiary educations. This shows that operating a cell phone, irrespective of their sophistication may not be a problem to the respondents.

The occupational levels of the respondents are almost evenly distributed amongst the occupations which were listed. However $30.33 \%$ of them are on paid employments which may either be with Government or privately owned enterprise. On marital status, it was discovered that more than half of the respondents are

Table 2: Socio-economic background of respondents in percentage

\begin{tabular}{lrr} 
Variables & Frequency & Percentage \\
\hline Age (years) & & \\
$<20$ & 156 & 26.00 \\
$21-40$ & 208 & 34.67 \\
$41-60$ & 165 & 30.83 \\
$>61$ & 51 & 8.50 \\
Total & 600 & 100.00 \\
Higher education & & \\
No formal education & 21 & 3.50 \\
Primary education & 102 & 17.00 \\
Secondary education & 228 & 38.00 \\
Tertiary education & 249 & 41.50 \\
Total & 600 & 100.00 \\
Occupation & & \\
Artisan & 94 & 15.67 \\
Farming & 72 & 12.00 \\
Trading & 116 & 19.33 \\
Salary earning & 182 & 30.33 \\
Business man & 136 & 22.67 \\
Total & 600 & 100.00 \\
Marital status & & \\
Single & 221 & 36.83 \\
Married & 337 & 56.17 \\
Separated & 42 & 7.00 \\
Total & 600 & 100.00 \\
\hline
\end{tabular}




\section{J. Mobile Commun., 4 (3): 68-74, 2010}

Table 3: Perception of respondents on incidence of road accident

\begin{tabular}{lcc}
\hline Variables (age) & Frequency & Percentage \\
\hline $\begin{array}{l}\text { Road factors (Bad road, sharp corners, } \\
\text { narrow roads, small bridges etc.) }\end{array}$ & 193 & 32.17 \\
$\begin{array}{l}\text { Human factors (Drunkenness, smoking of } \\
\begin{array}{l}\text { Talking, while driving, inexperience drivers, } \\
\text { over-speeding etc. }\end{array}\end{array}$ & 249 & 41.50 \\
$\begin{array}{l}\text { Vehicle factors (improper vehicle maintains, } \\
\text { break problem }\end{array}$ & 101 & 16.83 \\
$\begin{array}{l}\text { Weather factors (Harmattan, fog rain etc.) } \\
\text { Total }\end{array}$ & 57 & 9.50 \\
\hline
\end{tabular}

married $(57.17 \%)$ while as high as $(36.83 \%)$ of the respondents are single. This shows that both single and married (93\%) constitute the buck of the respondents for this study and these categories of people have high tendencies to interact through the use of GSM than the divorced. However, the tendencies for the single to interact physically is more than that of married people because of their natures, wants, demands and delinquencies as revealed by field interview and observations.

Table 3 shows the summary of how the people of Ondo Sate perceive the cause of accidents in their geographical environment. Past studies have also shown that four (a) major causes of accidents are common in any area or zone. According to Onakomaiya (1981), the four causes of accident are road factors, human factors, vehicle factors and weather factors.

The perception of the people of Ondo State on causes of road accident shows that human factor which manifest in form of drunkenness, smoking while driving, distraction, while driving, over speeding and inexperienced driving account for $41.5 \%$ of the accident in the State. It is pertinent to note however that among the factors listed as courses of accident, the human factor has the highest percentage.

Road factor accounted for $32.17 \%$ of the accident that occurred in Ondo State as perceived by the respondents. The road factor manifests in form of bad roads, sharp corners, narrow roads and bridges and pot holes. It is unfortunate that some of the roads in the state still have many dotted points of pot holes which made smooth driving difficult. Apart from this, the pot holes cause a lot of accidents to visitors passing through the state occasionally because they may not be used to the condition of the road network.

Vehicle and weather factors accounted for 16.83 and $9.50 \%$, respectively of the accidents that occurred in Ondo as perceived by respondents in Ondo State. The weather factor is common during rainy season and harmattan period when visibility becomes low as a result of the formation of fog and smog in the environment during certain period of the year.
Nigeria, according to Corporate Nigeria, has a road network of about $193,000 \mathrm{~km}$ and the road sector carries over $90 \%$ of domestic passengers and freight. This $90 \%$ which domestic passengers and freight carry made the road network to be saturated by commuters prior the introduction of G.S.M. However, with the introduction of GSM, the travel behaviour of Nigerians started to change. The rate at which commuters shifted from the use of automobiles to the use of GSM was unprecedented in the history of Nigeria.

At Nigerian independence in 1960, with a population of about 45 million people, the country only had about 18,724 phone lines for use. This translated to a Tele-density of about 0.5 telephone lines per 1000 people. The telephone network consisted of 121 exchanges of which 116 were of the manual type and only 5 were automatic.

Between independence in 1960 and 1985, telecom services become commercialised. The old department of Post and Telecommunication ( $\mathrm{P}$ and $\mathrm{T}$ ) under the Ministry of Communications became separated and Nigeria External Telecommunications limited (NET) was created to take care of external telecoms service while the old P and $\mathrm{T}$ handled the internal network (Eni, 2008). By January 1985, the erstwhile $\mathrm{P}$ and $\mathrm{T}$ merged with NET to form Nigeria Telecommunication Limited (NITEL). The objective of establishing NITEL was to harmonize the planning and coordination of the internal and external communication services, nationalize investment and external communication services, rationalize investment in Telecoms development and provide accessible, efficient and affordable services (Eni, 2008).

On May 29, 1999, the democratic government recognized the need for the telecom sector reform (Nigeria Business Information, 2005).

Deregulation of the telecoms sector that followed the reform, led to the granting of licenses to GSM service providers. The GSM recorded a boost in 2001 with the licensing of telecoms companies such as Econnet wireless Nig. Ltd (later Celtel now Zain), MTN, Globacom and lately the Etisalat.

In a bid to open up the sector and increase the range of services available to Nigerians, the Nigerian Communication Commission ( $\mathrm{NCC}$ ), also introduced the unified license regime in 2006 which allows mobile operators to offer an array of services ranging from voice, internet, high speed circuited for wireless mobile, switch data broadband, general packet radio system and universal telecommunication services under a single platform (Okereocha, 2008). 
With this development and coupled with the fact that handset and lines became cheap, the people of Nigeria and Ondo State in particular shifted from the use of automobiles to the use of GSM for their interaction. Table 4, revealed that $79 \%$ of the respondents relied on cell phone as against automobile usage to interact within the state on Mondays and Fridays. An earlier study by Ogunbodede (2005) also revealed that afternoon peak period travel have been greatly reduced by the use of GSM, while it has impact minimally on morning and evening peak period travels within the city of Lagos.

The travel behaviour of committers in Ondo State has changes as physical movement is now being replaced by the use of cell phones. This is made possible because owning a phone is no longer a status symbol as was the case before the revolution when it was exclusive preserve of the few rich. Today, market women, students, artisans, apprentice and government workers own at least a mobile phone.

The trend of owning a phone has changed as more people now own more than one mobile phone. Table 1 revealed that $50.67 \%$ owned one cell phone, $43.67 \%$ owned two cell phones, while 4.5 and $1.17 \%$ of the respondents owned three and four cell phone, respectively. The implication is that more are now

Table 4: Reliance on Cell phone Usage as Against Automobile to Interact within the State on Mondays and Fridays

\begin{tabular}{lcc}
\hline Sampled towns & $\begin{array}{c}\text { Rely on cell phone } \\
\text { for most interaction }\end{array}$ & $\begin{array}{c}\text { Rely on automobile for } \\
\text { interaction (physical contact) }\end{array}$ \\
\hline Akure & 82.0 & 18 \\
Owo & 79.0 & 21 \\
Ikare & 83.0 & 17 \\
Ondo & 86.0 & 14 \\
Ore & 71.0 & 29 \\
Okitipupa & 73.0 & 27 \\
Total & 47.4 & 126 \\
Percentage & 79.0 & 21 \\
\hline
\end{tabular}

Table 5: $\chi^{2}$ analysis showing level of reliance on cell phone usage as against physical contacts to interact in Ondo State, Nigeria

\begin{tabular}{lcc}
\hline Alpha levels & 0.05 & 0.01 \\
\hline Tabulated x2 & 11.070 & 15.090 \\
Calculated x2 & 85.318 & 85.318 \\
\hline $\mathrm{D} / \mathrm{F}=(\mathrm{r}-1)(\mathrm{c}-1)=5$ & &
\end{tabular}

interested in commuting within or outside Ondo State using more then one network. This is made possible because of the drastic reduction in the cost of acquiring handsets as well as the lines. Similarly, different type of marketing promotion occurs between the services providers in order to win more customers.

This study further went ahead to test the null hypothesis that commuters do not rely on cell phone usage as they do for automobiles to interact within the State. Chi Square $\left(\chi^{2}\right)$ was used to test this hypothesis. The result shows that calculated $\chi^{2}$ was greater than the critical value (tabulated value) of 11.07 and 15.09 under 0.05 and 0.01 confidence level, respectively.

Since the calculated $\chi^{2}$ is greater than the tabulated value, we reject the null hypothesis and accept the alternate which states that the people of Ondo State relied on cell phone usage to interact than the use of automobiles during Mondays and Fridays (Table 5).

Table 6, which was recorded using a perception scale is made up of 9 statement items to determine the impact of cell phone usage on travel behaviour in Ondo State.

The MWV of each item was determined as well as the GAM. The GAM was used as baseline for the acceptance and rejection of a statement item. The MWV was also used to rank the problem items. People who preferred the use of cell phone to physical movement within the State ranked 1 st, the rate at which people acquire cell phone in the last 3 years ranked 2 nd, preference for cell phone usage to physical movement ranked 3rd, cell phone usage is cheaper than physical movement ranked 4th, while people believed that continues usage of cell phone will reduce accident on roads ranked 5 th.

All these problem items (1st to 5th) were accepted based on the fact that their WMV of $228.5,226.4,223.0,221.7$ and 219.9 were higher than the GAM of 219.5 which was set as the baseline for acceptance. Others were rejected because they fell below the GAM (Table 6).

Table 6: Impact of cell phone usage on travel behaviour in Ondo State

\begin{tabular}{|c|c|c|c|c|c|c|c|c|c|}
\hline Impacts & SA & A & $\mathrm{D}$ & SD & $\mathrm{A} \%$ & $\mathrm{D} \%$ & MWV & Rank & Remark \\
\hline$t$ which people acquire cell phone in Ondo State is very high & 509 & 53 & 31 & 07 & 93.7 & 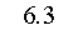 & 26.4 & 2nd & t \\
\hline refer cell phone usage to physical movement within the town & 527 & 38 & 26 & 09 & 94.2 & 5.8 & 228.5 & 1st & ccept \\
\hline refer cell phone usage to physical movement between towns in Ondo State & 495 & 40 & 40 & 21 & 89.2 & 10.8 & 223.0 & $3 r d$ & Accept \\
\hline if I have to deliver goods betw & 401 & 167 & 19 & 13 & 94.7 & 5.3 & 215.6 & 8th & ected \\
\hline 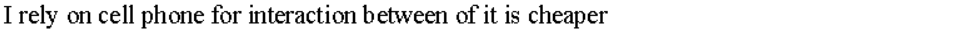 & 498 & 42 & 39 & 21 & 90.0 & 10.0 & 221.7 & 4th & \\
\hline & 409 & 159 & 17 & 15 & 94.7 & 5.3 & 216.2 & 7th & ted \\
\hline & 346 & 202 & 38 & 14 & 91.3 & 8.7 & 208.0 & 9th & ed \\
\hline & 418 & 148 & 16 & 18 & 94.3 & 5.7 & 216.5 & 6th & \\
\hline Continuous reliance on cell phone may reduce the rate or & 485 & 51 & 42 & 22 & 89.3 & 10.7 & 219.9 & 5th & Accepted \\
\hline
\end{tabular}

GAM $=219.5$ 


\section{CONCLUSION}

The summary of this study is that cell phone usage has increased inter-urban interaction as well as reduced physical movement. It has also reduced frequency of using automobiles which could have been more without the use of GSM.

The study also shows that social visits have been reduced drastically to calls while official duties have been enhanced through calls rather than physical movement.

\section{RECOMMENDATIONS}

Based on the discussions, it becomes imperative to recommend the following:

- Telecom operators should further increase the reliability of their network as well as per minute callcost

- The Nigerian Communication Commission. (NCC) should monitor the activities of the providers to ensure that the standard of services to customers is maintained

- Telecommuting should be encouraged in Ondo State so as to further reduce physical contact

- NCC should facilitate private sectors participation in communication services delivery, coordinate and regulate the activities of service delivery and fair pricing

- Services from network providers should be monitored in order to ensure that reliable and efficient services are made available to subscribers in order to further reduce physical contacts for information delivery

The consensus of respondents shows that given more conducive environment in terms of service delivery and fair pricing of GSM, people are ready to replace physical movement with cell phone usage during Mondays and Fridays.

The cheaper and more reliable the GSM becomes, the more patronage will be witnessed by service providers and the less will be physical contacts for intra-urban and inter-urban movements.

\section{REFERENCES}

Adenle, J.A., 1995. Role of telecommunication in the enhancement of transportation system in Nigeria: An overview. J. Transports Stud., 1: 46-55.

Bello, S.A., 1994. Urban public transport in a growing city: The case of Ilorin. Ph.D. Thesis, Submitted to the Department of Geography, University of Ilorin, Ilorin, Nigeria.

Berry, B.J.L., 1960. Internal structure of the city. Low Contemporary Problems, 30: 111-119.

Daniels, P.W. and A. Warnes, 1980. Movement in Cities. Methnern Publisher, London.

Eni, H., 2008. Telecoms Development in Nigeria-The Journey So Far. Tell Magazine, Nigeria, pp: 37-39.

Galtima, M., 1988. Changing pattern of urban growth the implication for transport system development in Nigeria. Trainer, 1: 5-18.

Hay, A. and R.H.T. Smith, 1970. Inter-Regional Trade and Money Flows in Nigeria. Oxford University Press, London.

Hook, W., 1995. Economic importance of non-motorized transportation. Trans. Res. Record, 1487: 14-21.

Mokhatarian, P.L. and R. Meenakshisundaram, 1999. Beyond tele-substitution: Disaggregate congitudinal structural equation and modeling of communication impact. Trans. Res. Part C, 7: 33-52.

NPC. (National Population Commission), 2006. Provisional Population of Nigeria. National Population Commission Publisher, Nigeria.

Ogunbodede, E.F., 2005. Cell phone usage in Lagos, Nigeria and potential implications for peak-period travel. Geografia, 30: 455-470.

Ogunsanya, A.A., 1982. Traffic congestions in an urban center: The case of Ilorin, Nigeria. Nig. Geographical J., 27: 84-95.

Okereocha, C., 2008. Seven years of Telecoms RevolutionOne Revelotion, a Thousand Gains. Tell Magazine, Nigeria.

Olufayo, O.O. and B.J. Omotosho, 2008. Social implications of GSM on Nigeria: A study of ifako ijaye local government area, Lagos, Nigeria. J. Mobile Commun., 1: 36-41.

Onakomaiya, S.O., 1981. Understanding Road Accidents in Nigeria: Some Preliminary. In: Transportation in Nigerian National Development, Onakomaiya, S.O. and N.F. Ekanem (Eds.). NISER., Ibadan, Nigeria, pp: 445-459. 